\title{
Catching up, absorption capability and the organisation of human capital
}

Citation for published version (APA):

Lankhuizen, M. (1998). Catching up, absorption capability and the organisation of human capital. MERIT, Maastricht Economic Research Institute on Innovation and Technology. MERIT Research Memoranda No. 014 https://doi.org/10.26481/umamer.1998014

Document status and date:

Published: 01/01/1998

DOI:

10.26481/umamer.1998014

Document Version:

Publisher's PDF, also known as Version of record

\section{Please check the document version of this publication:}

- A submitted manuscript is the version of the article upon submission and before peer-review. There can be important differences between the submitted version and the official published version of record.

People interested in the research are advised to contact the author for the final version of the publication, or visit the DOI to the publisher's website.

- The final author version and the galley proof are versions of the publication after peer review.

- The final published version features the final layout of the paper including the volume, issue and page numbers.

Link to publication

\footnotetext{
General rights rights.

- You may freely distribute the URL identifying the publication in the public portal. please follow below link for the End User Agreement:

www.umlib.nl/taverne-license

Take down policy

If you believe that this document breaches copyright please contact us at:

repository@maastrichtuniversity.nl

providing details and we will investigate your claim.
}

Copyright and moral rights for the publications made accessible in the public portal are retained by the authors and/or other copyright owners and it is a condition of accessing publications that users recognise and abide by the legal requirements associated with these

- Users may download and print one copy of any publication from the public portal for the purpose of private study or research.

- You may not further distribute the material or use it for any profit-making activity or commercial gain

If the publication is distributed under the terms of Article $25 \mathrm{fa}$ of the Dutch Copyright Act, indicated by the "Taverne" license above, 


\title{
Catching Up, Absorption Capability and the Organisation of Human Capital
}

\author{
Maureen Lankhuizen**
}

MERIT

\begin{abstract}
In order to identify, assimilate and exploit knowledge spill-overs from technological leaders, lagging countries need absorption capability. The main determinant of absorption capability is the organisation of R\&D personnel. Relatively more research scientists and engineers must be employed in the productive sector than in the university and public research sector. To increase the absorptive capacity of the productive sector it is necessary that enterprises engage in in-house R\&D activities. This conclusion implies that the possibilities to exploit the catching up potential are highest for countries whose initial technology gaps are relatively small. This is quite at odds with the conventional convergence hypothesis.
\end{abstract}

JEL Classification:

Keywords: technology gaps, catching up, research and development, human capital

* Financial support by the Netherlands Organisation for Scientific Research (NWO), grant 96/30462 SB107 HSo BD, is gratefully acknowledged. The grant has enabled me to work with the World Bank (Washington, D.C.) for three months.

** Maureen Lankhuizen, MERIT (Maastricht Economic Research Institute on Innovation and Technology), P.O. Box 616, 6200 MD Maastricht, the Netherlands. Tel. ++ 314338838 79, fax ++ 314332165 18, e-mail m.lankhuizen@merit.unimaas.nl 


\section{Introduction}

In this paper we study the ability of a lagging country to identify, assimilate, and exploit international knowledge spill-overs so as to reduce knowledge gaps with technological leaders and catch up. We call this ability a country's absorption capability ( $c f$ Cohen and Levinthal (1989)). In this paper we put forward new determinants of countries' absorption capability. We argue that, in addition to well qualified human capital, absorption capability requires the coordination and integration of various types of knowledge and a proper organisation of human capital. We show that the organisation of research scientists and engineers is foremost important for catching up. This conclusion illustrates the point by Cohen and Levinthal (1989) that "while R\&D obviously generates innovations, it also develops [firms'] ability to identify, assimilate, and exploit knowledge from the environment - what we call [firms'] 'learning' or 'absorptive' capacity" (Cohen and Levinthal (1989), p. 569) in a catching up context.

From the perspective of the convergence hypothesis, countries that lag behind technological leader countries enjoy so-called 'advantages of backwardness'. The source of these advantages lies in the opportunities that laggards have vis-à-vis technological leaders to assimilate knowledge developed by the leaders. Technological progress is generated by developing and diffusing new knowledge or new combinations of existing knowledge. One of the characteristics attributed to knowledge in new growth theory (see e.g. Romer (1990)) is that it is a non-rival good. In other words, once knowledge has been produced, it can be reproduced at little or no additional cost. This implies that countries that lag behind technological leaders can benefit from spill-overs from knowledge developed at the technological frontier. Whereas innovation and technological progress in leader countries is dependent on the production of new knowledge, and relatively small leaps of progress are consequently made, spill-overs from the leader countries may well increase the growth rate of the knowledge stock of laggards. Consequently, lagging countries can achieve a higher rate of technological progress and catch up with the leaders. In this respect the convergence hypothesis implies that, given the diffusion of knowledge, the larger the initial technology gap, the higher the catching-up potential.

Yet, exploitation of the catching-up potential by laggards may be restricted. In other words, there are limits to the 'advantages of backwardness'. Verspagen (1992) shows that a model of conditional catching up fits empirical data better than a model representing the 
convergence hypothesis. Whether or not lagging countries are able to increase the rate of technological progress and catch up with leaders in terms of the level of technology, in this model depends on the size of the initial knowledge gap and the countries' intrinsic ability to effectively absorb knowledge spill-overs. There are many (implicit) references to determinants of absorption capability in empirical studies, ranging from having a well developed stock of human capital (e.g. Baumol et al. (1989) and Verspagen (1992)) to social capabilities and technological congruence (Abramovitz (1986) and (1994)).

The paper is organised as follows. In section 2, we discuss the prerequisites for catching up. Section 3 presents a model illustrating the impact of the initial knowledge gap and absorption capability on catching up. This model will be estimated in section 4 to determine the relevance of absorption capability and the initial knowledge gap. Next, we will establish that it is not so much the stock of human capital as the organisation of this stock, in particular R\&D personnel, that matters for catching up. Section 5 concludes.

\section{Prerequisites for catching up}

The hypothesis that the larger the initial knowledge gap is, that separates a country from technological leaders, the higher the catching up potential, does not apply unconditionally. For a lagging country to be able to actually absorb knowledge from technological leaders, the initial gap should not be too wide. Moreover, a lagging country must have, or create, sufficient absorption capability. We will explain each of these prerequisites in turn.

First of all, growth of knowledge is highly cumulative and path-dependent: additions to a country's knowledge stock are in general in the vicinity of prior accumulated knowledge. If the stock of knowledge grows, additional learning is facilitated: "[r]esearch on memory development suggests that accumulated prior knowledge increases both the ability to put new knowledge into memory (...), and the ability to recall and use it." (Cohen and Levinthal (1990), p. 129) In other words, for a lagging country to be able to absorb knowledge from leader countries, it must have accumulated sufficient prior knowledge; the initial knowledge gap cannot be too wide.

Sufficient absorption capability implies, first of all, having qualified researchers who are able to understand external knowledge spill-overs and recognise their value in operation. In other 
words, a lagging country needs a strong human capital base with well developed scientific, engineering and technical skills.

Second, absorption capability is enhanced by the organisation of knowledge communication between various research organisations. Technological progress requires the mobilisation, co-ordination and integration of many different types of knowledge, and thus involves different types of knowledge producing organisations like firms, research institutes, and universities. ${ }^{1}$ This illustrates the strong link that exists between science and technology. Nelson and Rosenberg (1993) provide examples of the link between science and technology to show that the interaction is complex and varies between industries and technologies. For instance, technological progress in electrical equipment industries and the chemical industry is largely the result of advances in scientific disciplines as physics and chemistry. On the other hand, technology can also trigger off progress in science. The flying machine built by the Wright Brothers lead to new scientific fields like aerodynamics and aeronautical engineering, and progress in chemical industries gave way to chemical engineering. Yet, knowledge does not diffuse automatically between the various types of organisations involved in research. Part of the knowledge of organisations is stored in their routines (Nelson and Winter (1982)). It is often not codified, but only remembered by performing and is to a large extent specific to the organisation. This knowledge is not publicly available to other organisations. With repect to the co-ordination and integration of knowledge across the research sector then, communication or even interaction is needed. This can be accomplished by co-operation, strategic alliances, clusters, and networks, all of which install channels along which knowledge can be communicated.

Finally, a country's absorption capability is determined by the organisation of its human capital, in particular its $R \& D$ personnel. To achieve improvement of production technology, i.e. technological progress, on a large scale, relatively more scientists and engineers must be engaged in research directly integrated in production of goods and services as opposed to the university and public research sector. Notwithstanding that universities and public research institutes play an important role in developing new products and processes, the majority of research is done by firms (Nelson and Rosenberg (1993)). For new products or processes developed by universities or research and development (R\&D) institutes, both domestic and foreign, to be implemented in

\footnotetext{
${ }^{1}$ The statement applies to technological progress in the sense of developing new knowledge by a technological leader as well as in the sense of absorbing knowledge spill-overs by a lagging country.
} 
firms' production processes, the innovation must be adapted to firms' specific organisational structure and production processes. This implies that firms understand the innovation and are able to revise it. Firms will have to do research themselves (Cohen and Levinthal (1989)) and might even have to repeat parts of the original research process, since they have only partial knowledge about the innovation. This has important implications for the organisation of $R \& D$ personnel: they should be employed in production as well. More R\&D personnel in production of goods and services will increase the possibilities for absorption and diffusion in this sector. ${ }^{2}$

\section{A model of catching up}

Let us formalise the analysis about the possibilities of technologically lagging countries for catching up by following Verspagen (1992). Assume a follower country $f$ with a knowledge gap, $G_{0}$, relative to the technological frontier. To country $f$ the technological frontier is an external source of information. The growth rate of the knowledge stock in the lagging country is determined by the growth rate of knowledge resulting from its own 'exogenous' technological activity (i.e. the production and diffusion of new knowledge) $\beta_{f}$, and a diffusion or spill-over term, reflecting the opportunity for the lagging country to absorb knowledge from the technological frontier. So, we can the growth rate of the knowledge stock as:

$$
\kappa_{f}=\beta_{f}+\alpha_{f} G_{0} e^{-G_{0} / \delta_{f}}
$$

Because we want to focus on catching up through absorption of knowledge spill-overs, we take a country's own technological activities as given. ${ }^{3}$ The parameters $\alpha_{f}$ and $\delta_{f}$ are country-specific

\footnotetext{
2 The emphasis is on scientific organisations as the catalysts of technological progress and firms in an assimilating role. Of course, more human capital in production will also raise the autonomous innovative capability of this sector.

${ }^{3}$ Of course, a lagging country's own technological activity is not really exogenous. The effectiveness in producing and diffusing new knowledge depends on the country's own technological capabilities.
} 
parameters. The parameter $\delta_{f}$ reflects country $f$ 's absorption capability.

The diffusion term expresses that there are limits to the 'advantages of backwardness'. The exponential term indicates that in order to actually absorb external knowledge and increase the growth rate of the knowledge stock, the initial knowledge gap must not be too wide and the absorption capability must be sufficiently high. ${ }^{4}$ For small and intermediate levels of $G_{0}$, the effect of $\alpha_{f} G_{0}$, i.e. the 'advantage of backwardness'-effect, prevails and there are opportunities to increase the rate of knowledge accumulation through external knowledge spill-overs. However, for high levels of $G_{0}$ and given levels of $\delta_{f}$, the opportunities that a lagging country has vis à vis technological leaders to increase the growth rate of the knowledge stock due to spillovers, are eroded. The negative (positive) effect of large (small and intermediate) initial gaps on the growth of the knowledge stock in a lagging country is offset (reinforced) by its absorption capabilities, $\delta_{f}{ }^{5}$

Defining the technology gap in terms of differences in the knowledge stocks of the leader country and the follower country, respectively, i.e. $G=\ln \left(K_{l} / K_{f}\right)$, we can write the motion of the technology gap as

$$
\dot{G}=\kappa_{l}-\kappa_{f}
$$

where $\kappa_{l}$ and $\kappa_{f}$ denote the growth rate of the knowledge stock in the leader country and the

\footnotetext{
${ }^{4}$ Differentiating
}

$$
a_{f} G e^{-G / \delta_{f}}
$$

with respect to $G$, yields

$$
a e^{-G / \delta_{f}}-\frac{1}{\delta_{f}} a G e^{-G / \delta_{f}}
$$

For all values

$$
G>\delta_{f},
$$

the rate of knowledge accumulation through spill-overs will decrease.

\footnotetext{
${ }^{5}$ The growth rate of the knowledge stock increases for higher values of $\delta_{i f}$ and given levels of $\mathrm{G}_{0}$.
} 
follower country, respectively.

Substituting (1) in (2) yields

$$
\dot{G}=b-\alpha_{f} G_{0} e^{-G_{0} / \delta_{f}},
$$

where $b=\beta_{l}-\beta_{f}$.

The dynamics of the technology gap can be described as follows. Countries which are at some initial distance from the technological frontier can close the gap if the absorption capabilities are sufficiently high to enable the assimilation of spill-overs from or near the technological frontier. As we have seen it is a matter of developing the right skills and seeking to organise these skills in the right way across various research organisations, and organise knowledge communication across these organisations. Only then can country $f$ capture the advantages of backwardness and catch up. However, if the initial gaps are very large, absorption capabilities are likely to fail in closing the gap. The reason is that lagging countries need a minimum of prior knowledge to assimilate spill-overs effectively (Cohen and Levinthal (1990), Dahlman and Nelson (1993)). When absorption capabilities in country $f$ are too low to offset the size of the initial knowledge gap, the country will fall behind.

\section{Estimating the model}

In this section, we will test the hypothesis that actual absorption of knowledge by a follower country requires sufficient prior knowledge and sufficient absorption capability. Moreover we will try to establish that it is not just a qualified stock of human capital that matters for catching up, but rather the organisation of human capital. We argued that for a lagging country to absorb international knowledge spill-overs, and to subsequently achieve technological progress in the sense of improving production technologies in sectors like manufacturing and services, it is particularly important that sufficient human capital, more specifically $R \& D$ personnel, should be employed in the manufacturing and service sector. Relatively more R\&D 
personnel in manufacturing and services will increase the absorptive capacity of these sectors.

We use the following two equations:

$$
\dot{G}=c_{1}+a G_{0} e^{d\left(G_{0} / E\right)}+e_{1},
$$

where $c_{l}$ is the equivalent of $\beta_{l}-\beta_{f}$ in section 3 , and

$$
\dot{G}=c_{2}+b T+a G_{0} e^{d\left(G_{0} / E\right)}+e_{2}
$$

where $c_{2}$ is the equivalent of $\beta_{l}$ and $T$ denotes the follower country's own technological capability.

In equation (4), the research activity in the follower country, $\beta_{f}$, is exogenous and catching up is solely dependent on absorption of knowledge spill-overs. This is the model we focussed on mainly in section 3. In equation (5), the catch-up potential in the follower country depends on absorption of knowledge spill-overs as well as its own innovation capabilities. Both equations have $\delta$ appearing in the numerator as opposed to the denominator ( $c f$ equation (1)). Rather than being the parameter reflecting a country's absorption capability directly, $\delta$ is the coefficient measuring the relationship between the motion of the technology gap and absorption of knowledge spill-overs by the follower, where actual absorption is expected to decrease for high levels of the initial technology gap $G_{0}$ and to be positively related to the absorption capability $E$, as put forward in the previous section. This has been done to avoid problems in the estimation procedure (Verspagen (1992)).

The technology gap is defined as the real per capita GDP of the follower country relative to the United States. That is, $G=\ln \left(Q_{u s d} Q_{f}\right){ }^{6}$ The logarithmic specification reflects that, when the per capita GDP of a follower country equals the per capita GDP of the U.S., the gap is zero. The average motion of the technology gap has been obtained by OLS estimation of the time derivative of the gap over the period 1960-1985 for 119 countries. $G_{0}$ denotes the gap in 1960.

\footnotetext{
${ }^{6}$ Real per capita GDP is but a rough indicator of the technology level in a country, but "it is the only measure available in a country sample which is large enough to estimate the model." (Verspagen (1992), p. 121)
} 
Data have been taken from the Penn World Table (Mark 5.6). For $E$, the absorption capability, we use various indicators, the first two of which are indicators of the stock of human capital. The first indicator is the gross enrolment ratio in tertiary education in 1980, taken from the World Bank. Next, we define human capital more specifically in terms of technological skills. Our second indicator is the average number of scientists and engineers engaged in research and experimental development (RSEs) per million of population in the period 1973-1985, using UNESCO data for the number of RSEs and Penn World Table (Mark 5.6) for data on population. We use three indicators measuring the organisation of human capital. Each of these four indicators is obtained by averaging observations for the period 1973-1985. ${ }^{7}$ These indicators are also based on UNESCO data. All three capture the argument that to achieve technological progress in the sense of improving production technologies in manufacturing and services, it is particularly important that sufficient human capital should be employed in the manufacturing and service sector. The first indicator for the organisation of human capital is the share of RSEs integrated in the production of goods and services in the total number of RSEs. It explicitly indicates how much of the total technological skill potential is employed in manufacturing and services. The second indicator is the number of RSEs integrated in the production of goods and services per million of population. The third indicator denotes the share of RSEs integrated in the production of goods and services in total employment. Data on employment have been taken from ILO Yearbook of Labour Statistics. The country's own technological capability $T$ is measured by the same indicators plus the aggregate number of patents granted in the US in the period 1973-1985. The aggregate number of patents is taken to reflect the stock of accumulated prior knowledge in the country. This indicator reflects the argument by Cohen and Levinthal (1990). Patent data are taken from the U.S. Patent Office. Descriptive statistics are presented in the Appendix.

Using nonlinear least squares (NLS) estimation, we first estimate equation (4), using each of the indicators for $E$ separately. ${ }^{8}$ In all estimations we use the same indicator for $G_{0}$, so changes in the coefficient and the significance level of $d$, and the explanatory power of the model are

\footnotetext{
${ }^{7}$ The rationale for choosing this period is, first of all, data availability: for a large sample of countries, data are available on a more or less regular basis from the beginning of the 70s; and, second, we wanted to study the period before the break-up of socialism in Central and Eastern Europe.

${ }^{8}$ Table A2 in the Appendix indicates that the indicators for E are highly correlated. Therefore, each of the indicators is used separately.
} 
attributable to changes in the indicators used to measure the absorption capability $E$. Based on the theoretical analysis in section 3 , we expect $c_{1}, c_{2}>0$, and $a, b, d<0$. The results of all four estimations are shown in Table 1.

Estimation with the standard indicator for the quality of human capital (Education) as the indicator for $E$ has an extremely low explanatory power when based on 102 countries. Moreover, all parameters have the wrong sign. The results improve when estimating for a smaller sample of countries, as can be seen in equation 1.b. We have used the sample of countries for which equations 3-5 in Table 1a have been estimated, to facilitate comparison with equations 2-5. Equation 1.b does not confirm that catching up with technological leaders requires an initial knowledge gap which is not too large and sufficient absorption capability in the sense of well qualified human capital. It rather confirms the convergence hypothesis, i.e. the larger the size of the initial gap, the higher the faster the decline in the growth of the technology gap. The relationship put forward in equation (4), when estimated by the enrolment ratio in tertiary education, appears not to hold for OECD countries (equation 1.c): the sample coefficient of determination does increase, but this is probably due to a mere decrease in the variability of the dependent variable; two coefficients have the wrong sign, and none of them is significant.

We ran two tests with the indicator RSEs per million of population. In the first run, we include the number of scientists and engineers in research and experimental development per million of population of centrally planned economies, Czechoslovakia, German Democratic Republic, Hungary and Poland. The numbers are in full-time equivalents (ftes). However, socialist countries did not measure their research and development activities on the basis of Frascati Manual definitions (European Commission (1994)), so data for these countries are difficult to compare internationally. Moreover, socialist official data in general suffer from measurement problems, rendering them less reliable. ${ }^{9}$ The socialist data are "best practice estimates". (European Commission (1994), p. 183) To avoid distortions, we have excluded the socialist countries in the second run with the number of RSEs per million of population (equation 2.b). Using an alternative indicator for the quality of human capital (RSEs per million of population) improves the results. The parameters have the correct sign, albeit that $c_{l}$ is not significant.

9 See e.g. Bergson (1991), Desai (1986) and Ofer (1987) for more details on Soviet national account statistics. 
Table 1. Estimation results equation (4)

\begin{tabular}{|c|c|c|c|c|c|c|}
\hline eq. \# & indicators $E$ & $\hat{c}_{1}$ & $\hat{a}$ & $\hat{d}$ & $\mathrm{R}^{2}$ & $\mathrm{n}$ \\
\hline 1.a & Education & $\begin{array}{l}-0.01 \\
(-2.72)\end{array}$ & $\begin{array}{c}0.0024 \\
(1.45)\end{array}$ & $\begin{array}{c}0.0011 \\
(2.99)\end{array}$ & 0.1 & 102 \\
\hline $1 . b$ & Education & $\begin{array}{c}0.0047 \\
(0.84)\end{array}$ & $\begin{array}{c}-0.0177 \\
(-2.83)\end{array}$ & $\begin{array}{c}-0.0204 \\
(-1.22)\end{array}$ & 0.26 & 31 \\
\hline 1.c & Education & $\begin{array}{c}-0.0034 \\
(-0.73)\end{array}$ & $\begin{array}{c}-0.0033 \\
(-0.93)\end{array}$ & $\begin{array}{c}0.0956 \\
(1.93)\end{array}$ & 0.57 & 20 \\
\hline 2.a & $\begin{array}{l}\text { RSEs per million of } \\
\text { population }\end{array}$ & $\begin{array}{c}0.0046 \\
(0.85)\end{array}$ & $\begin{array}{c}-0.0193 \\
(-3.01)\end{array}$ & $\begin{array}{c}-102.6886 \\
(-2.17)\end{array}$ & 0.22 & 36 \\
\hline 2.b & $\begin{array}{l}\text { RSEs per million of } \\
\text { population }\end{array}$ & $\begin{array}{c}0.0030 \\
(0.57)\end{array}$ & $\begin{array}{l}-0.0195 \\
(-2.94)\end{array}$ & $\begin{array}{c}-140.3990 \\
(-2.13)\end{array}$ & 0.21 & 33 \\
\hline 3. & $\begin{array}{l}\text { The share of RSEs } \\
\text { integrated in production of } \\
\text { goods \& services in total } \\
\text { RSEs }\end{array}$ & $\begin{array}{c}0.0107 \\
(2.65)\end{array}$ & $\begin{array}{c}-0.0438 \\
(-5.33)\end{array}$ & $\begin{array}{c}-0.1114 \\
(-4.79)\end{array}$ & 0.57 & 32 \\
\hline 4. & $\begin{array}{l}\text { RSEs integrated in } \\
\text { production of goods \& } \\
\text { services per million of } \\
\text { population }\end{array}$ & $\begin{array}{c}0.0065 \\
(1.47)\end{array}$ & $\begin{array}{c}-0.0242 \\
(-4.86)\end{array}$ & $\begin{array}{c}-21.7655 \\
(-2.88)\end{array}$ & 0.45 & 32 \\
\hline 5. & $\begin{array}{l}\text { RSEs integrated in } \\
\text { production of goods \& } \\
\text { services per million of total } \\
\text { employment }\end{array}$ & $\begin{array}{c}-0.0007 \\
(-0.13)\end{array}$ & $\begin{array}{c}-0.0114 \\
(-2.06)\end{array}$ & $\begin{array}{c}-49.685 \\
(-0.78)\end{array}$ & 0.15 & 31 \\
\hline 6. & $\begin{array}{l}\text { Number of patents granted } \\
\text { in the US, } 1973-1985\end{array}$ & $\begin{array}{c}0.0001 \\
(0.01)\end{array}$ & $\begin{array}{c}-0.0125 \\
(-2.70)\end{array}$ & $\begin{array}{c}-3.6373 \\
(-0.77)\end{array}$ & 0.21 & 36 \\
\hline
\end{tabular}

The t-statistics are given in parentheses. 
The explanatory power is significantly increased, when using the share of RSEs integrated in production of goods and services in total RSEs as an indicator for a country's absorption capability (equation 3). All parameters have the expected sign and are significant, and $\mathrm{R}^{2}$ increases to 0.57 . The estimated value of $d$ seems to confirm that the technology gap increases for high levels of the initial knowledge gap and decreases when absorption capability rises. However, from the correlation matrix in Table A2 in the Appendix it can be seen that overall the size of the initial knowledge gap and the growth of the technology gap are negatively correlated. Thus the exponential term seems less dominated by the initial knowledge gap than by the absorption capability. An alternative way of testing the importance of prior knowledge is by using the aggregate number of patents granted in the U.S. in the period 1973-1985 in the denominator of equation (4). This means we test the hypothesis that catching up is solely dependent on having sufficient prior knowledge. The results are shown in equation 6 . It turns out that the patent variable is not significant, whereas the estimated value of $a$ is significantly negative, indicating that advantages of backwardness prevail. This indicates that limits to the 'advantages of backwardness' originate from the need to have sufficient absorption capability. These results point out the importance of a country's absorption capability for catching up. Equation 3 implies that the organisation of the total technological skill potential in particular is of great importance: a larger share of a country's technological skill potential employed in manufacturing and services implies a larger catching-up potential. The negative relation between growth of the technology gap and the share of RSEs integrated in production of goods and services in total RSEs is illustrated in Figure 1. When all countries for which data are available are included in the sample, the model explains nearly 60 per cent of the variability in the growth rate of the technology gap. Table 2 shows the results of estimations with the share of RSEs integrated in the production of goods and services in total RSEs for different country groups. It turns out that the explanatory power of the model is highest for market economies, and particularly, for OECD countries. So, for countries with relatively small initial gaps (as is the case for OECD countries), the organisation of R\&D personnel becomes particularly relevant for catching up. The estimated relationship between the growth rate of the technology gap and the organisation of human capital, in particular the technological skill potential, appears to fit data for centrally planned economies less than other country groups. Still, we do not consider centrally planned economies outliers, based on the empirical evidence presented in Figure 1. 
Figure 1. The motion of the technology gap plotted against the absorption capability

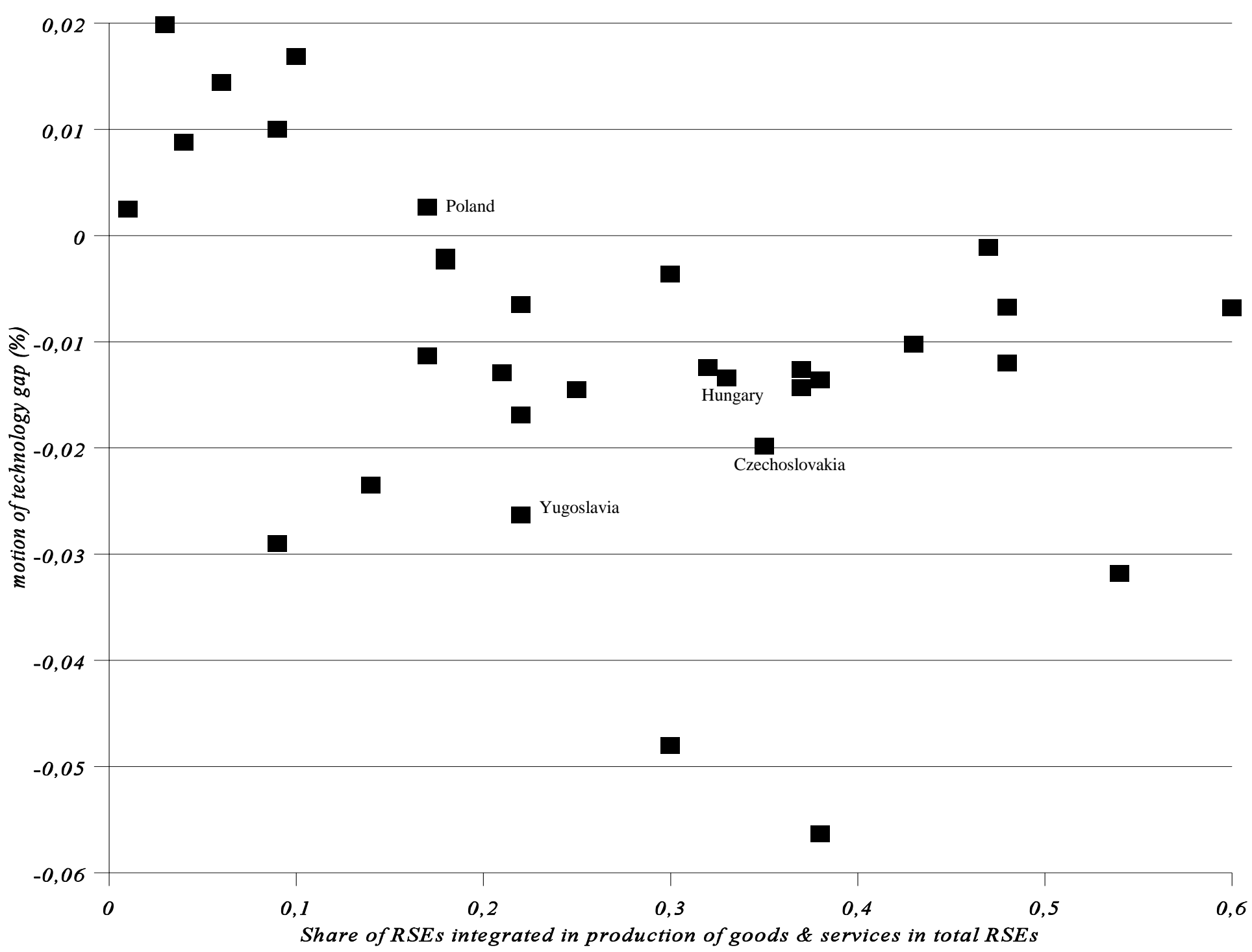


Table 2. Estimation results equation (4) for the share of RSEs integrated in production of goods \& services in total number of RSEs

\begin{tabular}{|l|c|c|c|c|c|}
\hline country groups & $\hat{c}_{1}$ & $\hat{a}$ & $\hat{d}$ & $\mathrm{R}^{2}$ & $\mathrm{n}$ \\
\hline $\begin{array}{l}\text { 1 Industrialised econo-mies, } \\
\text { i.e. omitting developing } \\
\text { countries }\end{array}$ & $\begin{array}{c}0.0108 \\
(2.39)\end{array}$ & $\begin{array}{c}-0.0414 \\
(-4.80)\end{array}$ & -0.0987 & 0.55 & 29 \\
\hline 2. Market economies, i.e. \\
omitting centrally planned
\end{tabular}

The t-statistics are given in parentheses.

An explanation for the lower explanatory power is probably the relatively wide differences within the group of centrally planned economies.

The second indicator for the organisation of human capital, measured as the number of RSEs integrated in production of goods and services per million of population, performs well, too. However, this indicator does not explicitly measure the organisation of the technological skill potential. Neither does the indicator measuring the number of RSEs integrated in production of goods and services per million of employment. This explains the lower explanatory power of equations 4 and 5. One might have expected the number of RSEs integrated in production of goods and services per million of employment to yield similar, or even better, results as the integrated in production of goods and services per million of population. Part of the difference between the coefficients of determination in equation 4 and 5 can be explained by splitting the sample into different country groups. From Table 3 it follows that the coefficient of determination for the number of RSEs integrated in production of goods and services per million of employment is low whenever developing countries are included in the sample. It seems that this indicator is not a particularly suitable one for developing countries. The number of RSEs integrated in production of goods and services per million of population is a better indicator for developing countries. This, in turn, can be explained by the fact that employment in developing 
Table 3. Estimation results equation (4) for RSEs integrated in production of goods \& services per million of total employment

\begin{tabular}{|c|c|c|c|c|c|}
\hline country groups & $\hat{c}_{1}$ & $\hat{a}$ & $\hat{d}$ & $\mathrm{R}^{2}$ & $\mathrm{n}$ \\
\hline 1. Total sample & $\begin{array}{c}-0.0007 \\
(-0.13)\end{array}$ & $\begin{array}{c}-0.0114 \\
(-2.06)\end{array}$ & $\begin{array}{c}-49.685 \\
(-0.78)\end{array}$ & 0.15 & 31 \\
\hline $\begin{array}{l}\text { 2. Market economies, i.e. } \\
\text { omitting centrally planned } \\
\text { economies }\end{array}$ & $\begin{array}{c}-0.0006 \\
(-0.11)\end{array}$ & $\begin{array}{c}-0.0127 \\
(-1.81)\end{array}$ & $\begin{array}{c}-57.3649 \\
(-0.81)\end{array}$ & 0.15 & 27 \\
\hline $\begin{array}{l}\text { 3. Industrialised econo- } \\
\text { mies, i.e. omitting } \\
\text { developing countries }\end{array}$ & $\begin{array}{c}0.0035 \\
(0.67)\end{array}$ & $\begin{array}{c}-0.0194 \\
(-3.34)\end{array}$ & $\begin{array}{c}-64.8064 \\
(-1.44)\end{array}$ & 0.34 & 28 \\
\hline 4. OECD countries & $\begin{array}{c}0.0115 \\
(2.40)\end{array}$ & $\begin{array}{c}-0.0388 \\
(-5.19)\end{array}$ & $\begin{array}{c}-71.205 \\
(-3.11)\end{array}$ & 0.67 & 20 \\
\hline
\end{tabular}

The t-statistics are given in parentheses.

countries is low compared to their populations.

Next, we test the extended model, represented by equation (5). Based on the foregoing estimation results, we only use the indicators for the organisation of human capital as the determinant of absorption capability. Table 4 presents the estimation results. It follows that the equations in which the absorption capability $E$ is denoted by the share of RSEs integrated in the production of goods and services in total RSEs yields the best results. However, the coefficient of the country's own technological capability $T$ is nowhere significant (equations 1-5). In other words, extending the model does not add very much to its explanatory power. The high coefficient of determination in equation 5 is the result of the sample: patent data are only available for OECD countries. The results in Table 2 have illustrated that the model fits OECD countries particularly well. The same remark with respect to the high coefficient of determination holds for equations 10 and 15. 
Similar to the findings in Table 1, the explanatory power of the extended model is lower when the number of RSEs integrated in the production of goods and services per million of population and the number of RSEs integrated in the production of goods and services per million of employment are used as an indicator of the organisation of human capital. Note that the coefficient of absorption is significant in all equations with the number of RSEs integrated in the production of goods and services per million of population, except when the indicator for the country's own technological capability is denoted by the share of RSEs integrated in the production of goods and services in total RSEs (i.e. equation 8). At the same time, the coefficient of the country's own technological capability is nowhere significant, except when measured by the share of RSEs integrated in the production of goods and services in total RSEs. The coefficient of absorption is insignificant in all equations with the number of RSEs integrated in the production of goods and services per million of employment. ${ }^{10}$ Here too, the coefficient of the country's own technological capability is nowhere significant, except when measured by the share of RSEs integrated in the production of goods and services in total RSEs.

The evidence in Table 4 does not lend much support to the extended model of catching up. Catching up is only significantly dependent on a country's own technological capabilities when the share of RSEs integrated in the production of goods and services in total RSEs is the main factor determining catching up. In fact, a country's own technological activities are more or less captured already by the indicators for the absorption capability $E$ in the estimation of equation (5). More specifically, by the number of scientists and engineers engaged in research and experimental development. Thus $T$ has little value-added. Therefore, we adopt equation (4) to model catching up. Using the estimation results in Table 1, we can write this relationship as:

$$
\dot{G}=0.0107-0.0438 G_{0} e^{-0.1114\left(G_{0} / E\right)} .
$$
above.

${ }^{10}$ The exception is equation 15 , but, here, the level of significance is due to the country sample, as argued 
Table 4. Estimation results equation (5)

\begin{tabular}{|c|c|c|c|c|c|c|c|}
\hline indicators $T$ & indicators $E$ & $\hat{c}_{2}$ & $\hat{b}$ & $\hat{a}$ & $\hat{d}$ & $\mathrm{R}^{2}$ & $\mathrm{n}$ \\
\hline 1. Education & $\begin{array}{l}\text { The share of RSEs integrated } \\
\text { in production of goods \& } \\
\text { services in total RSEs }\end{array}$ & $\begin{array}{c}0.0178 \\
(2.61)\end{array}$ & $\begin{array}{c}-0.0297 \\
(-1.32)\end{array}$ & $\begin{array}{c}-0.0414 \\
(-5.31)\end{array}$ & $\begin{array}{c}-0.0935 \\
(-3.99)\end{array}$ & 0.59 & 31 \\
\hline $\begin{array}{l}\text { 2. Total number of RSEs per } \\
\text { million of population }\end{array}$ & & $\begin{array}{c}0.0086 \\
(2.05)\end{array}$ & $\begin{array}{c}0.0000 \\
(1.35)\end{array}$ & $\begin{array}{l}-0.0526 \\
(-4.77)\end{array}$ & $\begin{array}{c}-0.1304 \\
(-4.92)\end{array}$ & 0.59 & 31 \\
\hline $\begin{array}{l}\text { 3. RSEs integrated in production } \\
\text { of goods \& services per million } \\
\text { of population }\end{array}$ & & $\begin{array}{l}0.01 \\
(2.40)\end{array}$ & $\begin{array}{c}0.0000 \\
(0.64)\end{array}$ & $\begin{array}{c}-0.0485 \\
(-4.24)\end{array}$ & $\begin{array}{c}-0.1234 \\
(-4.17)\end{array}$ & 0.57 & 31 \\
\hline $\begin{array}{l}\text { 4. RSEs integrated in production } \\
\text { of goods \& services per million } \\
\text { of total employment }\end{array}$ & & $\begin{array}{c}0.0093 \\
(2.03)\end{array}$ & $\begin{array}{c}0.0000 \\
(0.67)\end{array}$ & $\begin{array}{c}-0.0473 \\
(-4.40)\end{array}$ & $\begin{array}{l}-0.1214 \\
(-4.25)\end{array}$ & 0.56 & 31 \\
\hline $\begin{array}{l}\text { 5. Patents granted in the US, } \\
\text { 1973-1985 }\end{array}$ & & $\begin{array}{c}0.0156 \\
(4.45)\end{array}$ & $\begin{array}{c}0.0000 \\
(0.12)\end{array}$ & $\begin{array}{c}-0.0535 \\
(-6.57)\end{array}$ & $\begin{array}{c}-0.0936 \\
(-4.8)\end{array}$ & 0.83 & 22 \\
\hline 6. Education & $\begin{array}{l}\text { RSEs integrated in production } \\
\text { of goods \& services per } \\
\text { million of population }\end{array}$ & $\begin{array}{c}0.0142 \\
(1.83)\end{array}$ & $\begin{array}{c}-0.0304 \\
(-1.23)\end{array}$ & $\begin{array}{c}-0.0247 \\
(-4.93)\end{array}$ & $\begin{array}{c}-18.113 \\
(-2.63)\end{array}$ & 0.48 & 31 \\
\hline
\end{tabular}




\begin{tabular}{|c|c|c|c|c|c|c|c|}
\hline $\begin{array}{l}\text { 7. Total number of RSEs per } \\
\text { million of population }\end{array}$ & & $\begin{array}{c}0.0039 \\
(0.69)\end{array}$ & $\begin{array}{c}0.0000 \\
(0.82)\end{array}$ & $\begin{array}{c}-0.0272 \\
(-4.22)\end{array}$ & $\begin{array}{c}-27.252 \\
(-2.18)\end{array}$ & 0.47 & 31 \\
\hline $\begin{array}{l}\text { 8. The share of RSEs integrated } \\
\text { in production of goods \& } \\
\text { services in total RSEs }\end{array}$ & & $\begin{array}{c}0.0168 \\
(2.72)\end{array}$ & $\begin{array}{c}-0.0393 \\
(-2.36)\end{array}$ & $\begin{array}{c}-0.0209 \\
(-4.47)\end{array}$ & $\begin{array}{c}-13.633 \\
(-2.13)\end{array}$ & 0.55 & 31 \\
\hline $\begin{array}{l}\text { 9. RSEs integrated in production } \\
\text { of goods \& services per million } \\
\text { of total employment }\end{array}$ & & $\begin{array}{c}0.0064 \\
(1.16)\end{array}$ & $\begin{array}{c}-0.0000 \\
(-0.17)\end{array}$ & $\begin{array}{c}-0.0234 \\
(-4.33)\end{array}$ & $\begin{array}{c}-20.956 \\
(-2.38)\end{array}$ & 0.43 & 31 \\
\hline $\begin{array}{l}\text { 10. Patents granted in the US, } \\
1973-1985\end{array}$ & & $\begin{array}{c}0.0123 \\
(3.26)\end{array}$ & $\begin{array}{c}0.0000 \\
(0.10)\end{array}$ & $\begin{array}{c}-0.0416 \\
(-6.72)\end{array}$ & $\begin{array}{c}-28.4095 \\
(-3.73)\end{array}$ & 0.78 & 21 \\
\hline 11. Education & $\begin{array}{l}\text { RSEs integrated in production } \\
\text { of goods \& services per } \\
\text { million of total employment }\end{array}$ & $\begin{array}{c}0.0133 \\
(1.20)\end{array}$ & $\begin{array}{l}-0.051 \\
(-1.54)\end{array}$ & $\begin{array}{c}-0.0135 \\
(-2.64)\end{array}$ & $\begin{array}{c}-18.843 \\
(-0.52)\end{array}$ & 0.23 & 30 \\
\hline $\begin{array}{l}\text { 12. Total number of RSEs per } \\
\text { million of population }\end{array}$ & & $\begin{array}{c}0.0034 \\
(0.44)\end{array}$ & $\begin{array}{c}-0.0000 \\
(-0.87)\end{array}$ & $\begin{array}{c}-0.0108 \\
(-2.11)\end{array}$ & $\begin{array}{l}-24.58 \\
(-0.42)\end{array}$ & 0.18 & 31 \\
\hline $\begin{array}{l}\text { 13. The share of RSEs integra- } \\
\text { ted in production of goods \& } \\
\text { services in total RSEs }\end{array}$ & & $\begin{array}{c}0.0243 \\
(2.83)\end{array}$ & $\begin{array}{c}-0.0698 \\
(-3.71)\end{array}$ & $\begin{array}{c}-0.0138 \\
(-3.60)\end{array}$ & $\begin{array}{c}2.5822 \\
(0.31)\end{array}$ & 0.43 & 31 \\
\hline $\begin{array}{l}\text { 14. RSEs integrated in produc- } \\
\text { tion of goods \& services per } \\
\text { million of population }\end{array}$ & & $\begin{array}{c}0.0053 \\
(0.75)\end{array}$ & $\begin{array}{l}-0.0000 \\
(-1.74)\end{array}$ & $\begin{array}{c}-0.0101 \\
(-2.27)\end{array}$ & $\begin{array}{c}-0.0000 \\
(-0.00)\end{array}$ & 0.20 & 31 \\
\hline
\end{tabular}




\begin{tabular}{|l|l|c|c|c|c|c|}
\hline $\begin{array}{l}\text { 15. Patents granted in the US, } \\
1973-1985\end{array}$ & & $\begin{array}{c}0.0116 \\
(2.33)\end{array}$ & $\begin{array}{c}-0.0000 \\
(-0.14)\end{array}$ & $\begin{array}{c}-0.0384 \\
(-4.69)\end{array}$ & $\begin{array}{c}-69.2898 \\
(-2.62)\end{array}$ & $\begin{array}{c}0.67 \\
21\end{array}$ \\
\hline
\end{tabular}

The t-statistics are given in parentheses. 


\section{Conclusion}

In order to increase the rate of technological progress and catch up with technological leaders in terms of the level of technology, lagging countries must effectively absorb knowledge spill-overs. This paper has shown that a country's absorption capability is to some extent dependent on having a large stock of highly qualified R\&D personnel. Yet, more important than the size of the $R \& D$ potential per se is its organisation. Research scientists and engineers must be employed in the productive sector to a large extent as opposed to the university and public research sector. It is particularly in the improvement of technology used in the production of goods and services that technological progress takes effect. To increase the absorptive capacity of the productive sector it is necessary that enterprises engage in in-house R\&D activities. Thus this paper illustrates the relevance of the Cohen and Levinthal (1989) argument in a catching up context. This conclusion implies that the possibilities to exploit the catching up potential are highest for countries whose initial technology gaps are relatively small. This is confirmed by the results: the number of research scientists and engineers integrated in production of goods and services in total number is particularly significant for OECD countries. Consequently, countries that do not engage in enterprise R\&D to some extent will fall behind. This is quite at odds with the hypothesis that the larger the initial technology gap is, the larger the catching up potential. 


\section{References}

Abramovitz, M. (1986), 'Catching Up, Forging Ahead, and Falling Behind', Journal of Economic History, 66, pp. 385-406.

Abramovitz, M. (1994), 'The Origins of the Postwar Catch-up and Convergence Boom', in Fagerberg, J., Verspagen, B. and von Tunzelman, N. (eds), The Dynamics of technology, trade and growth, Aldershot, Edward Elgar Publishing, Ltd.

Baumol, W., Batey Blackman, S.A. and Wolff, E. (1989), Productivity and American Leadership. The Long View, Cambridge, MA and London, MIT Press.

Cohen, W.M. and Levinthal, D.A. (1989), 'Innovation and Learning: The Two Faces of R\&D', The Economic Journal, 99, pp. S.569-596.

Cohen, W.M. and Levinthal, D.A. (1990), 'Absorptive Capacity: A New Perspective on Learning and Innovation' in Administrative Science Quarterly, No. 35, pp. 128-152.

Dahlman, C. and Nelson, R. (1993), Social Absorption Capability, National Innovation


Institute for New Technologies (UNU/INTECH), Maastricht, The Netherlands, June 21231993.

European Commission (1994), The European Report on Science and Technology Indicators, Brussels.

Nelson, R.R. and Rosenberg, N. (1993), ‘Technical Innovation and National Systems’, in Nelson, R.R. (ed.), National Innovation Systems: A Comparative Study, Oxford: Oxford University Press, pp. 3-21.

Nelson, R.R. and Winter, S.G. (1982), An Evolutionary Theory for Economic Change, Cambridge MA: Harvard University Press.

Romer, P.M. (1990). 'Endogenous Technological Change', in Journal of Political Economy, 98, S71-S102.

Verspagen, B. (1992). Uneven Growth Between Interdependent Economies. An Evolutionary View on Technology Gaps, Trade and Growth, Maastricht: Universitaire Pers Maastricht. 


\section{Appendix}

The motion of the technology gap has been estimated for the following 119 countries: Algeria, Angola, Benin, Botswana, Burundi, Cameroon, Central African Republic, Chad, Congo, Egypt, Ethiopia, Gabon, Gambia, Ghana, Guinea, Ivory Coast, Kenya, Lesotho, Liberia, Madagascar, Malawi, Mali, Mauritania, Mauritius, Morocco, Mozambique, Niger, Nigeria, Rwanda, Senegal, Seychelles, Sierra Leone, Somalia, South Africa, Sudan, Swaziland, Tanzania, Togo, Tunisia, Uganda, Zaire, Zambia, Zimbabwe, Barbados, Canada, Costa Rica, Dominican Republic, El Salvador, Guatemala, Haiti, Honduras, Jamaica, Mexico, Nicaragua, Panama, Trinidad \& Tobago, Argentina, Bolivia, Brazil, Chile, Colombia, Ecuador, Guyana, Paraguay, Peru, Suriname, Uruguay, Venezuela, Bangladesh, Hong Kong, India, Iran, Iraq, Israel, Japan, Jordan, Republic of Korea, Malaysia, Nepal, Pakistan, Philippines, Saudi Arabia, Singapore, Sri Lanka, Syria, Taiwan, Thailand, Austria, Belgium, Cyprus, Czechoslovakia, Denmark, Finland, France, German Democratic Republic, Federal Republic of Germany, Greece, Hungary, Iceland, Ireland, Italy, Luxembourg, Malta, Netherlands, Norway, Poland, Portugal, Romania, Spain, Sweden, Switzerland, Turkey, United Kingdom, USSR, Yugoslavia, Australia, Fiji, New Zealand, Papua New Guinea.

The countries for which data on the organisation of human capital are available are: Egypt, Mauritius, Senegal, Canada, Mexico, Trinidad \& Tobago, Argentina, Chile, Peru, Venezuela, Japan, Jordan, Republic of Korea, Singapore, Sri Lanka, Austria, Czechoslovakia, Denmark, Finland, France, Federal Republic of Germany, Hungary, Ireland, Italy, Netherlands, Norway, Poland, Portugal, Spain, Sweden, Yugoslavia, and Australia.

Tables A1 and A2 show some descriptive statistics of the variables used and the correlation matrix, respectively. The independent variables are highly correlated in most cases. As a result, we do not test the model using multiple indicators for a country's absorption capability simultaneously. 
Table A1. Descriptive Statistics

\begin{tabular}{|l|c|c|}
\hline variables & Mean & Standard Deviation \\
\hline$\dot{\mathrm{G}}$ & -0.0134 & 0.018 \\
\hline $\mathrm{G}_{0}$ & 0.8982 & 0.5899 \\
\hline Education & 0.2365 & 0.0996 \\
\hline $\begin{array}{l}\text { RSEs per million of } \\
\text { population }\end{array}$ & 1118.10 & 889.629 \\
\hline $\begin{array}{l}\text { The share of RSEs } \\
\text { integrated in production of } \\
\text { goods \& services in total } \\
\text { RSEs }\end{array}$ & 0.3073 & 0.1474 \\
\hline $\begin{array}{l}\text { RSEs integrated in } \\
\text { production of goods \& } \\
\text { services per million of } \\
\text { population }\end{array}$ & 424.709 & 481.331 \\
\hline $\begin{array}{l}\text { RSEs integrated in } \\
\text { production of goods \& } \\
\text { services per million of total } \\
\text { employment }\end{array}$ & 999.181 & 1047.61 \\
\hline $\begin{array}{l}\text { Patents granted in the US, } \\
1973-1985\end{array}$ & 9702.23 & 22636.5 \\
\hline
\end{tabular}


Table A2. Correlation Matrix

\begin{tabular}{|c|c|c|c|c|c|c|c|c|}
\hline & $\dot{\mathrm{G}}$ & $\mathrm{G}_{0}$ & Education & $\begin{array}{l}\text { RSEs per } \\
\text { million of } \\
\text { population }\end{array}$ & $\begin{array}{c}\text { The share of RSEs } \\
\text { integrated in } \\
\text { production of } \\
\text { goods \& services in } \\
\text { total RSEs }\end{array}$ & $\begin{array}{l}\text { RSEs integrated in } \\
\text { production of } \\
\text { goods \& services } \\
\text { per million of } \\
\text { population }\end{array}$ & $\begin{array}{l}\text { RSEs integrated in } \\
\text { production of } \\
\text { goods \& services } \\
\text { per million of total } \\
\text { employment }\end{array}$ & $\begin{array}{l}\text { Patents granted } \\
\text { in the US, } \\
1973-1985\end{array}$ \\
\hline$\dot{\mathrm{G}}$ & 1.0 & & & & & & & \\
\hline Education & 0.24 & -0.69 & 1.0 & & & & & \\
\hline $\begin{array}{l}\text { RSEs per million of } \\
\text { population }\end{array}$ & -0.07 & -0.38 & 0.54 & 1.0 & & & & \\
\hline $\begin{array}{l}\text { The share of RSEs } \\
\text { integrated in production } \\
\text { of goods \& services in } \\
\text { total RSEs }\end{array}$ & -0.4 & -0.18 & 0.60 & 0.63 & 1.0 & & & \\
\hline $\begin{array}{l}\text { RSEs integrated in } \\
\text { production of goods \& } \\
\text { services per million of } \\
\text { population }\end{array}$ & -0.15 & -0.24 & 0.52 & 0.95 & 0.73 & 1.0 & & \\
\hline
\end{tabular}


RSEs integrated in

production of goods \&

$-0.13-0.25$

0.53

0.93

0.75

0.99

1.0

services per million of

total employment

Patents granted in the

$-0.2-0.02$

0.32

0.77

0.54

0.88

0.84

1.0

US, 1973-1985 